\section{Synoviosarcoma of arm in 4-month-old infant reconstructed with sensate free anterolateral thigh flap}

Sir,

Soft-tissue sarcoma of the upper limb is rare tumour. ${ }^{[1]}$ Only $15 \%$ of soft-tissue sarcomas occur in extremity. ${ }^{[2]}$ The most common histologic subtypes of soft-tissue sarcoma seen in the hand are epitheloid sarcoma, synovial sarcoma and malignant fibrous histiocytoma. ${ }^{11]}$ The synovial sarcoma arising in the arm and that too in the 4-month-old infant is rare. ${ }^{[3-5]}$

A 4-month-old infant was brought with complaints of rapidly growing swelling in the right arm with ulceration and bleeding for 35 days [Figure 1]. There was no history of any comorbid illness. No other relevant history was elicitable. Clinical examination revealed an active infant with normal nutrition. There was a firm ovoid swelling measuring $4.5 \mathrm{~cm} \times 3 \mathrm{~cm} \times 3 \mathrm{~cm}$ attached to biceps brachii muscle with $2 \mathrm{~cm} \times 3 \mathrm{~cm}$ ulceration at its summit, which was bleeding on manipulation [Figure 1]. There were no regional lymph node enlargements. Incisional biopsy was reported as synovial sarcoma. Metastatic workup revealed no spread of tumour to distant sites. Appropriate informed consent for the surgery was obtained from the parents including consent for the use of clinical data and pictures for research studies.

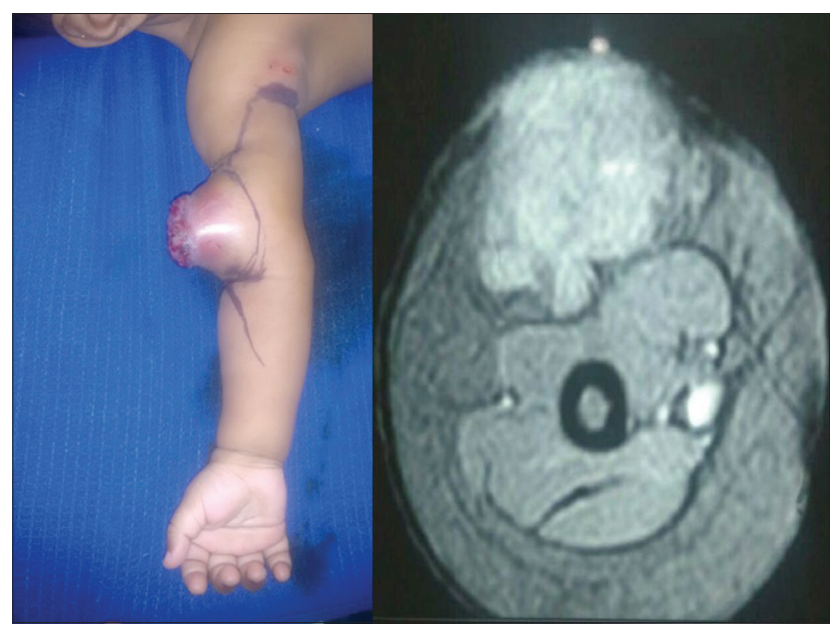

Figure 1: A 4-month-old baby with synoviosarcoma of the arm (left). Magnetic resonance imaging showing infiltration into biceps muscle (right)
The surgical oncologists under general anaesthesia did wide local excision of the tumour with $2.5-\mathrm{cm}$ margin. Resultant defect was measuring $8 \mathrm{~cm} \times 6 \mathrm{~cm}$. There was only small residuum of the long head of biceps with exposure of radial nerve and musculocutaneous nerve over the brachialis muscle in the bed of the excised defect [Figure 2].

With pattern of the defect, $8.5 \mathrm{~cm} \times 6 \mathrm{~cm}$ free anterolateral free flap was harvested with lateral femoral cutaneous nerve. Recipient vessels were musculocutaneous perforator from the brachial artery and tributary to brachial vein. The sizes of vessels were from $0.75 \mathrm{~mm}$ to $0.8 \mathrm{~mm}$. Single vein anastomosis was done. Operating microscopes with $\times 20$ magnification were used for anastomosis. Lateral femoral cutaneous nerve was anastomosed to anterior branch of medial cutaneous nerve of the arm [Figure 3]. Donor site was closed primarily.

Immunohistochemical examination of the excised specimen revealed the spindle cells in whorls, glandular pattern and vimentin and TLE-1(Transducin Like Enhancer split -1) positive ${ }^{[6]}$ [Figure 3] confirming the pre-operative pathology study as synovial sarcoma - monophasic. It was Stage IA tumour (G1T1bN0 M0). Tumour margins were declared free. Therefore, tumour board of our institution declared no need for any adjuvant therapy.

The infant was followed for 12 months postoperatively. Flap and donor sites settled well [Figure 4]. There was

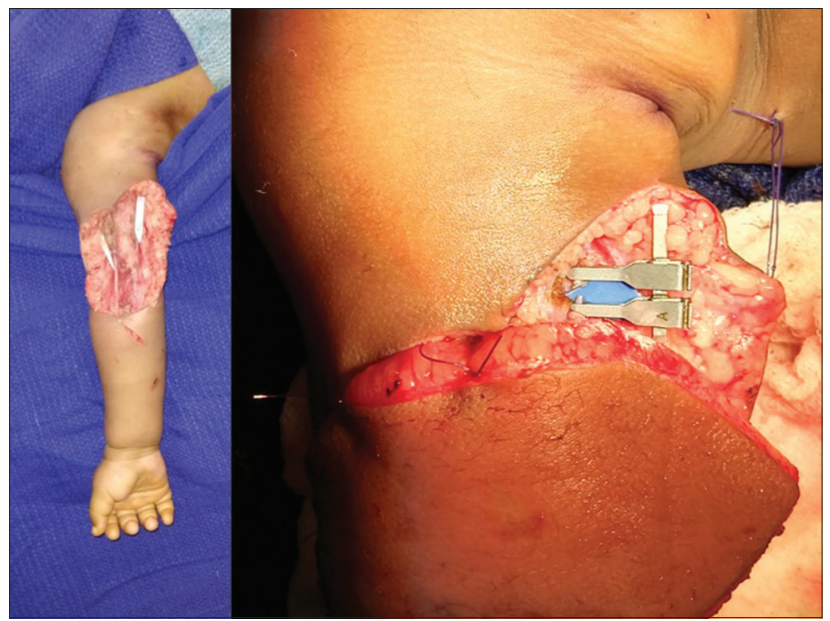

Figure 2: After wide local excision showing the exposure of neurovascular bundles (left). Supermicrovascular anastomosis (right) 


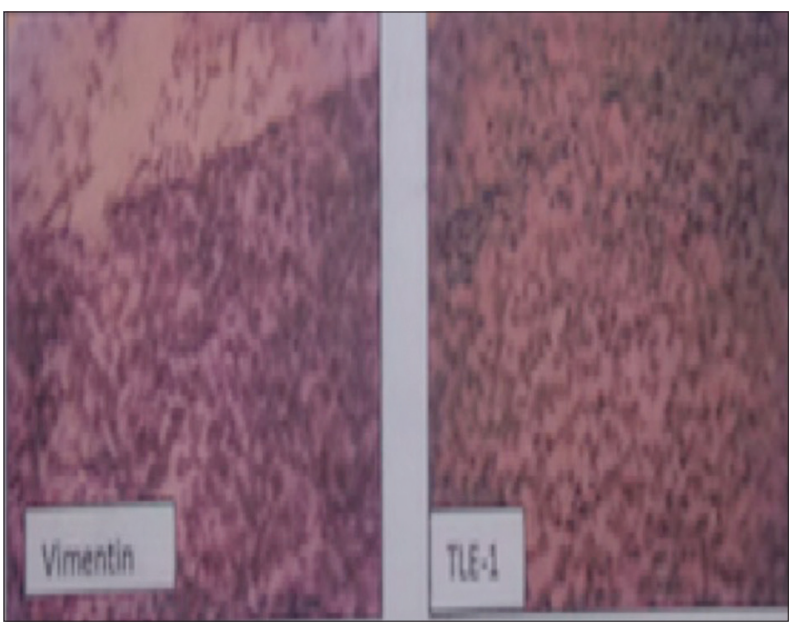

Figure 3: Vimentin and Transducin like Enhancer split -1 (TLE-1)-positive monophasic synoviosarcoma

neither any locoregional recurrence nor any distant metastases. There was good functional recovery of the right elbow function with no distal deficit.

Surgery is the most common modality of treatment for the synovial sarcoma and advocated as the primary modality for the locoregional control of the disease. ${ }^{[7]}$ The goal of the surgical treatment is excision of tumour with cuff of normal tissue three dimensionally. Tumour was fixed to biceps brachii and the greatest dimension was $<5 \mathrm{~cm}$ (T1b tumour). In this case, it was in the uncommon site as the common site being the carpus and fingers in the upper limb and also not in relation to any joints, tendons or bursae. ${ }^{[8,9]}$ Quite contrast to its grade, it was growing aggressively, and thus, histological grade was not truly predictive of biological behaviour of the tumour. ${ }^{[10]}$ Considering the stage of the disease, it was decided for the limb preservation surgery. As the tumour in this case was not violating the fascia between the brachialis and biceps brachii, it was possible for the wide local excision with reasonable margin, with preservation of brachial neurovascular bundles and radial and musculocutaneous nerves. However, the surgical oncologists excised the most portions of biceps. Considering the resultant defect, single-stage free anterolateral thigh flap was planned and was done with intraoperative consultation confirming the tumour-free margins as per the current consensus in the management of synovial sarcoma. ${ }^{[11,12]}$ The donor site morbidity was almost nil as the secondary defect was closed primarily. The neurotisation, in this case, was done to improve the local proprioception paving the way for early recovery. One-year disease-free survival was obtained in this case and baby remained healthy.

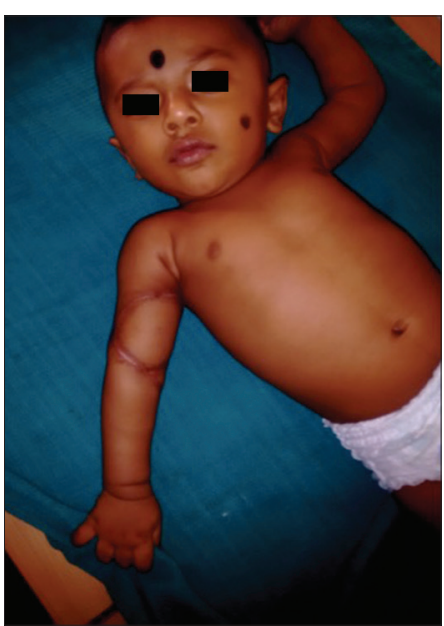

Figure 4: Late post-operative picture

Despite the aggressive nature of tumour, a well-executed wide local excision with single-stage reconstruction with free flap can be a good choice for these uncommon malignant tumours occurring in the infants. Advancements in super microsurgery and infant anaesthesia pave the way for achieving the limb preservation in these types of rare malignant tumours of the infants.

\section{Declaration of patient consent}

The authors certify that they have obtained all appropriate patient consent forms. In the form the patient(s) has/have given his/her/their consent for his/her/their images and other clinical information to be reported in the journal. The patients understand that their names and initials will not be published and due efforts will be made to conceal their identity, but anonymity cannot be guaranteed.

\section{Financial support and sponsorship}

Nil.

\section{Conflicts of interest}

There are no conflicts of interest.

Balakrishnan Margabandu Thalaivirithan, Harsha Subbaraj, Jaganmohan Janardhanam

Department of Plastic and Faciomaxillary Surgery, Madras Medical College, Chennai, Tamil Nadu, India

Address for correspondence: Dr. Balakrishnan Margabandu Thalaivirithan Old No 15, New No10, Thiruvalluvar Street, NTR Road, Rangarajapuram, Kodambakkam, Chennai - 600024

Tamil Nadu, India.

E-mail: thalaiviri.b@gmail.com

\section{REFERENCES}

1. Brien EW, Terek RM, Geer RJ, Caldwell G, Brennan MF, 
Healey JH, et al. Treatment of soft-tissue sarcomas of the hand. J Bone Joint Surg Am 1995;77:564-71.

2. Lewis JJ, Brennan MF. Soft tissue sarcomas. Curr Probl Surg 1996;33:817-72.

3. Wushou A, Miao XC. Tumor size predicts prognosis of head and neck synovial cell sarcoma. Oncol Lett 2015;9:381-6.

4. Daum R. Malignant tumors in infancy and childhood. Chirurg 1996;67:584-92.

5. Yang GH, Zhao F. Primary study of histogenesis and diagnosis of synoviosarcoma. Hua Xi Yi Ke Da Xue Xue Bao 1989;20:285-9.

6. Terry J, Saito T, Subramanian S, Ruttan C, Antonescu CR, Goldblum JR, et al. TLE1 as a diagnostic immunohistochemical marker for synovial sarcoma emerging from gene expression profiling studies. Am J Surg Pathol 2007;31:240-6.

7. Terek RM, Brien EW. Soft-tissue sarcomas of the hand and wrist. Hand Clin 1995;11:287-305.

8. Cameron HU, Kostuik JP. A long-term follow-up of synovial sarcoma. J Bone Joint Surg Br 1974;56-B:613-7.

9. Dick HM. Synovial sarcoma of the hand. Hand Clin 1987;3:241-5.

10. Oda Y, Hashimoto H, Tsuneyoshi M, Takeshita S. Survival in synovial sarcoma. A multivariate study of prognostic factors with special emphasis on the comparison between early death and long-term survival. Am J Surg Pathol 1993;17:35-44.

11. Talbot SG, Mehrara BJ, Disa JJ, Wong AK, Pusic A, Cordeiro PG, et al. Soft-tissue coverage of the hand following sarcoma resection. Plast Reconstr Surg 2008;121:534-43.
12. Thomas BP, Sasi K, Pallapati SC, Mathew A, Sreekanth R, Thomas $\mathrm{M}$, et al. Malignant tumours of the hand and wrist. Indian J Plast Surg 2011;44:337-47.

This is an open access journal, and articles are distributed under the terms of the Creative Commons Attribution-NonCommercial-ShareAlike 4.0 License, which allows others to remix, tweak, and build upon the work non-commercially, as long as appropriate credit is given and the new creations are licensed under the identical terms.

\begin{tabular}{|l|l|}
\hline \multicolumn{2}{|c|}{ Access this article online } \\
\hline Quick Response Code: & Website: \\
\hline & www.ijps.org \\
\cline { 2 - 2 } & DOI: \\
\hline
\end{tabular}

How to cite this article: Thalaivirithan BM, Subbaraj $H$, Janardhanam J. Synoviosarcoma of arm in 4-month-old infant reconstructed with sensate free anterolateral thigh flap. Indian $\mathrm{J}$ Plast Surg 2018;51:338-40.

(c) 2019 Indian Journal of Plastic Surgery | Published by Wolters Kluwer - Medknow 